\title{
A preliminary study of flow directions of Tertiary hyaloclastites and pahoehoe lava flows on Svartenhuk Halvø, West Greenland
}

\section{Jørgen Gutzon Larsen}

Field work on Svartenhuk Halvø in connection with the 1:100 000 map was started in 1980 and a preliminary description of the basalts is reported here. This work is a continuation of the mapping further south on Ubekendt Ejland (1:100 000 map sheet Igdlorssuit 71 V. 1 Syd, Larsen, in press). A brief summary of the basalts from Svartenhuk Halvø is given by Clarke \& Pedersen (1976). The present work is concerned with the olivine-rich basalts of the lower formation in which flow directions were deduced from foreset bedding in the hyaloclastites (cf. Fuller, 1931) and inclination of pipe amygdales in pahoehoe lava flows (cf. Du Toit, 1907; Waters, 1960; Schmincke, 1967). The aim was to locate the palaeoslope and source areas.

Within the graben area of eastern Svartenhuk Halvø (fig. 7) the exposed thickness of the lower formation is approximately $1300 \mathrm{~m}$ and includes a $150-500 \mathrm{~m}$ thick base of hyaloclas-

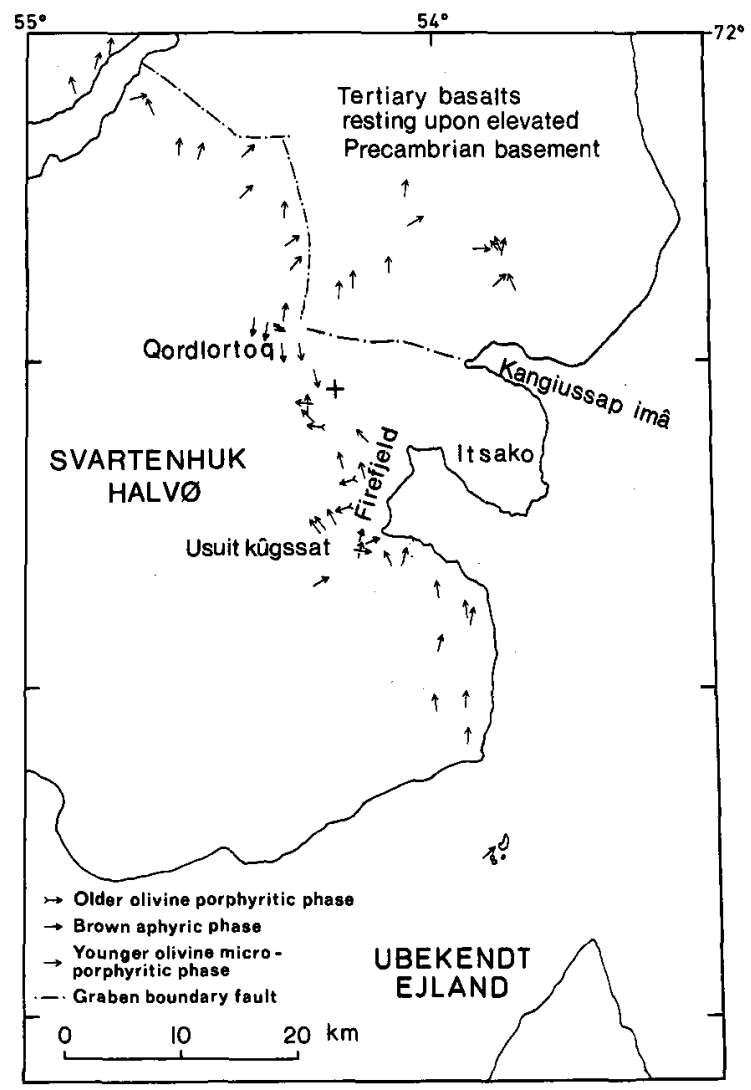

Fig. 7. Dip directions of the foreset bedding in the hyaloclastites. Graben boundary fault after Rosenkrantz \& Pulvertaft (1969), 
Fig. 8. Pipe amygdales in pahoehoe lava flows.

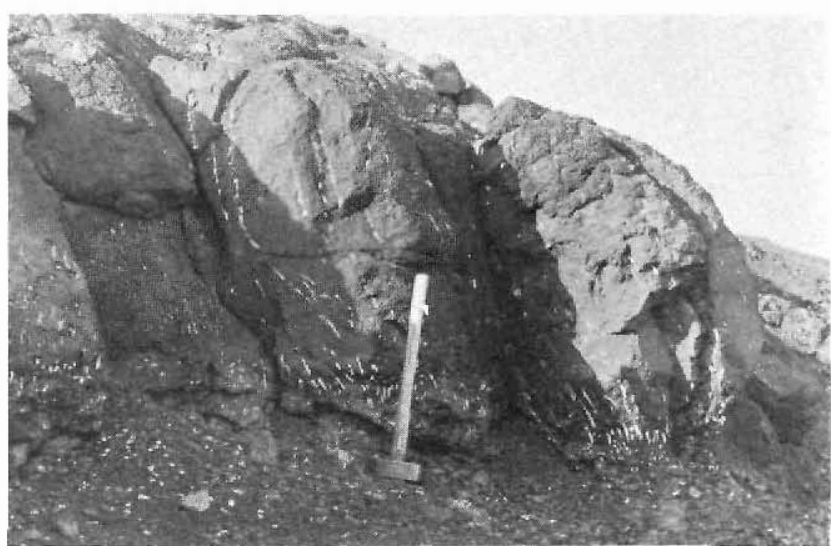

tites which increases in thickness towards the north. They were formed during several eruptions of olivine porphyritic and microporphyritic grey hyaloclastites contemporary with a brown aphyric hyaloclastite. The earliest hyaloclastites are interbedded with shales which occasionally contain transported plant remains, whereas interbedded lava flows occur higher in the sequence especially to the south-east. The lava flows of the lower formations are dominated by olivine porphyritic and microporphyritic basalts of the compound pahoehoe type formed by many $0.2-3 \mathrm{~m}$ thick lava tongues reaching total thicknesses of more than 100 $\mathrm{m}$. Pauses in the volcanism are indicated by thin clastic beds.

The hyaloclastites exhibit large scale foreset bedding with dip directions shown in fig. 7. It should be noted that in some cases the orientation of the foreset bedding has been deduced from apparently low dips. The limited amount of exposure excludes establishment of a regional flow pattern for the earliest hyaloclastite, but westward flow into a deep lake is observed in the region west of Firefjeld. This hyaloclastite is overlain to the south by a brown aphyric hyaloclastite in which bedding planes are in many places indistinct and which is often interbedded with irregular jointed lava sheets. Brown aphyric lava flows related to this eruption occur further to the west in Usuit kugssuat, and they run into breccia facies towards the east with north-east dipping foreset beds. Brown aphyric hyaloclastite at Qordlortoq shows large scale southwards dipping foreset beds and is presumably related to another eruption. In general, north-west to north-east bedding dips dominate in the young phase of olivine bearing hyaloclastites. This is also true for those of reduced thickness on the elevated Precambrian basement north-east of the graben boundary fault. Possible eruptive sites are indicated by intense dyke formation and veining of olivine microporphyritic basalts in the grey hyaloclastite a few kilometres north-west of Firefjeld, in an area with different bedding dips. These intrusions were not observed in the overlying lavas. An intersected feeder dyke was also found in this area. Furthermore, feeder dykes which go into pillow breccia facies are present in the hyaloclastites north of Kangiussap imâ, as well as in the brown hyaloclastite at Qordlortoq. It seems therefore likely that some of the early eruptions took place to the east, along the graben boundary fault, while others occurred south-west and south of Svartenhuk Halvø. 


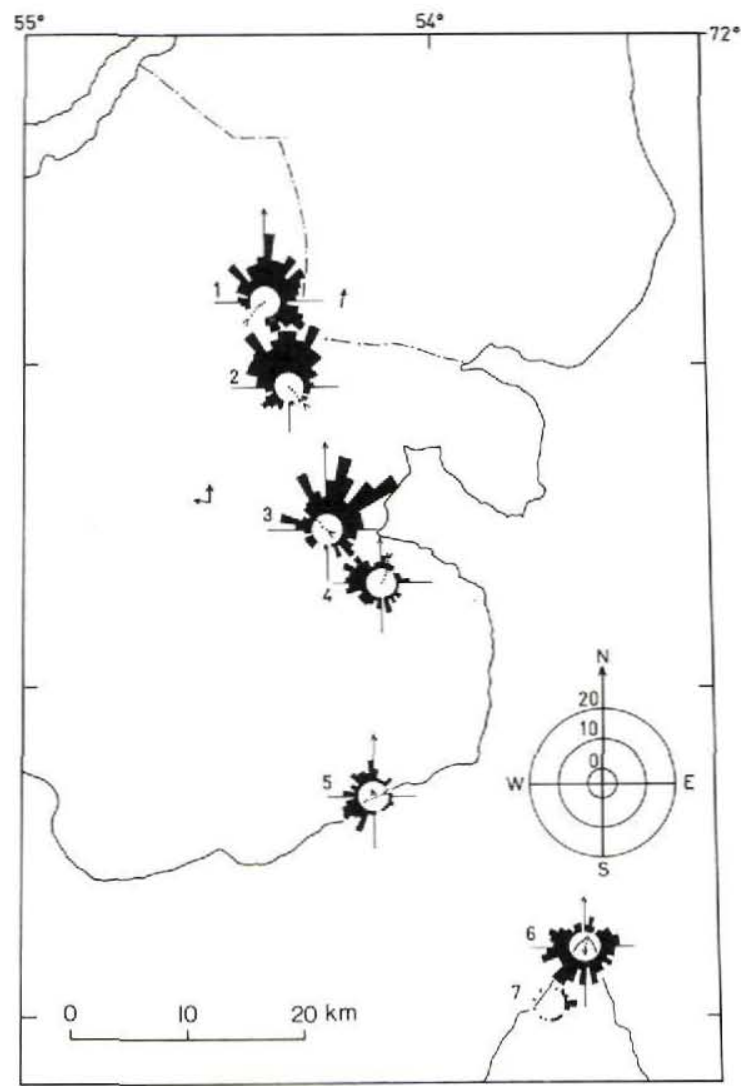

Fig. 9. Pipe amygdale flow roses in lavas of the lower formation divided in $10^{\circ}$ intervals. A scale for the number of measurements is shown. Arrows give rough estimates where directions were not measured. Profile directions are shown by stippled line.

Flow directions of the pahoehoe lava flows of the lower formation have been measured from the orientation of the pipe amygdales representing trapped gas which tried to rise vertically through the flowing lava from the base (fig. 8). The direction of deflection along the flow bases was measured by compass at a distance of approximately $1 \mathrm{~m}$ in order to reduce magnetic deviations imposed from the lava, which were slight and insignificant in relation to the spread in flow directions. However, in the vicinity of the dykes, it was impossible to obtain any reliable results. As the best inland exposures occur in the steep mountain sides, along the mountain ridges, and in the gorges, the measurements were made in profiles. The exposures were carefully searched for flow directions opposite to that of the profile as these are not so easily visible. This method only enabled the tracing of individual flow units over short distances (generally less than $100 \mathrm{~m}$ ), but even so measurements in single thin lava tongues may show a scatter of more than $180^{\circ}$, presumably due to deviations in the pipe amygdales along the edges of these lava tongues. More constant flow directions were observed in the thicker flow units. The results of 84 to 210 measurements in six profiles are shown in fig. 9 together with a few observations in other areas. Changes in flow direction are related to profile heights in fig. 10. Profiles $1-4$ start at the top of the hyaloclastite and profiles 5 and 6 are believed to belong to the lower part of the lower formation. The profiles 


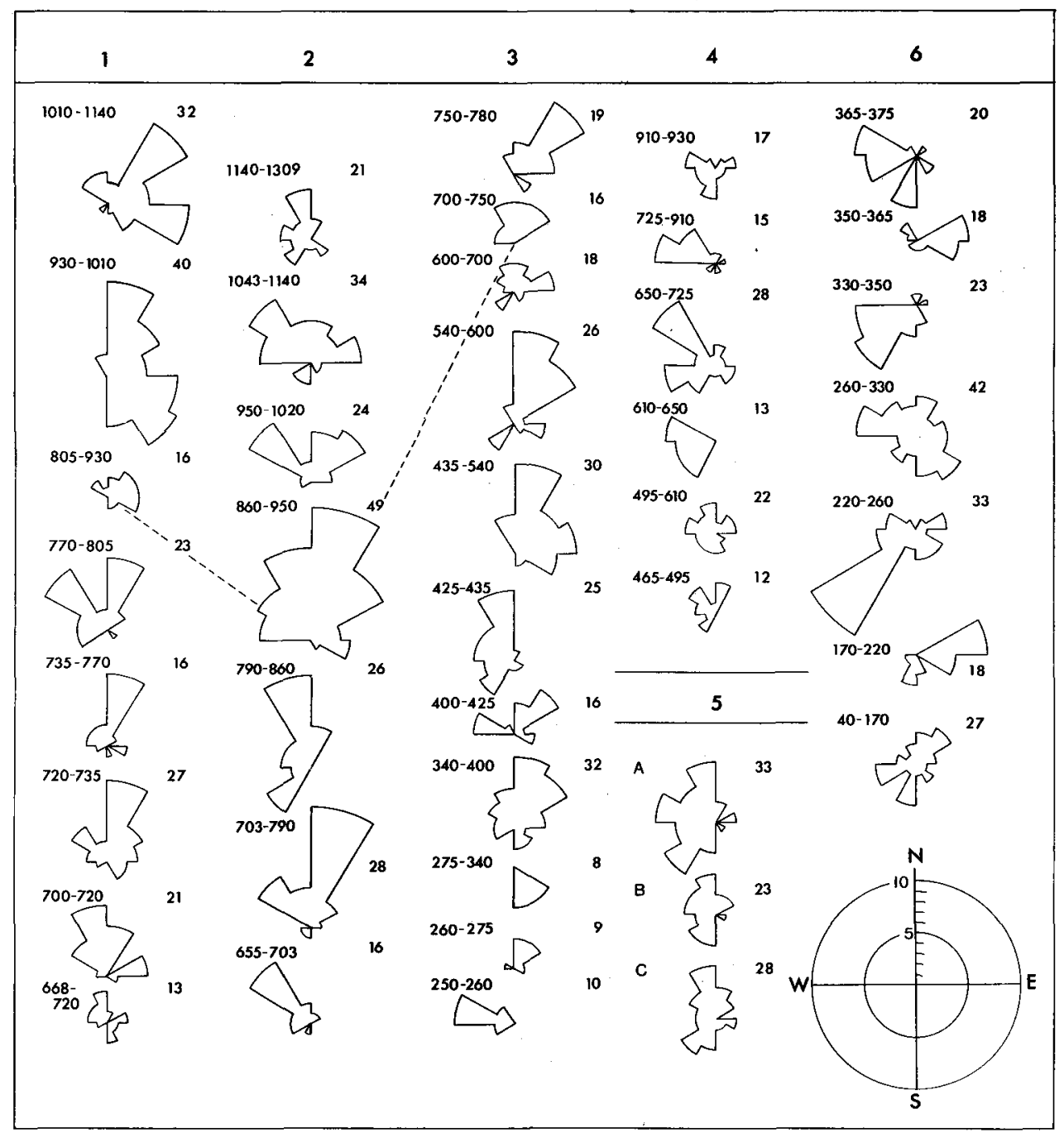

Fig. 10. Pipe amygdale flow roses divided in $30^{\circ}$ intervals related to profile height in metres. A scale for the number of measurements is shown in the lower right corner and the total amount of data for each rose is given on the right. A: strongly dipping lava flows $\left(\leqslant 45^{\circ}\right)$ east of a NNE-SSW trending fault along the shore. B: slightly dipping lava flows $\left(\sim 18^{\circ}\right)$ west of fault. C: strongly dipping lava flows in a gorge.

cover lava thicknesses of 375-700 m (except no. 5) but only no. 2 reaches the top of the lower formation. An approximate stratigraphical correlation is indicated in fig. 4 , and in some cases similar flow patterns may be correlated.

Dominating northerly flow directions are observed in profiles 1-3 and agree with the 
general dip of the young grey hyaloclastite, but in profile 1 it is opposite to that of the brown hyaloclastite. Eastern flow directions dominate in the upper part of this profile. Although north-eastern flow directions dominate in the upper part of profile 3 , these cannot be correlated with that of no. 1 . Early north-west flow is suggested at the base of these profiles. On south-eastern Svartenhuk Halvø, the flow was mainly westerly with north-west maximum in profile 4 and northern and south-western maxima in profile 5. On northern Ubekendt Ejland, flow directions towards west-south-west and east dominate, whereas northern directions are scarce.

The basalts were erupted on a surface already levelled to a considerable degree by the hyaloclastites, and the lava flows presumably formed gently sloping plains $\left(<1^{\circ}\right)$ away from the eruption sites, similar to the situation in the young Snake River Plain described by Russel (1902, p. 102-103). The flow pattern may therefore be related to eruptions situated south of Svartenhuk Halvø, and other eruptions towards south-west, west and south-east to account for the flow directions in profiles 1-3. The flow pattern on south-eastern Svartenhuk Halvø and northern Ubekendt Ejland may be related to eruptions along the east coast of south-eastern Svartenhuk Halvø southwards to Ubekendt Ejland. Profile 5 may reflect interfingering between these eruptions and those to the south, perhaps situated west of Ubekendt Ejland and being responsible for the eastward flow directions here.

It appears from the preliminary study above, that pipe amygdale flow directions may provide a powerful tool to reveal possible eruption sites for the lower formation of Svartenhuk Halvø and possibly other places in the province where foreset bedded hyaloclastites are scarce. Such data may prove valuable in establishing a more detailed stratigraphy in the lower formation, which has proved very difficult due to lack of marker horizons and distinct chemical breaks. The present data suggest that source areas may be present in the on-shore areas and adjacent fjords. Further work may help to locate these more precisely.

Acknowledgements. The author thanks the skipper on K. J. V. Steenstrup, A. Viostein, for his co-operation and for a pleasant stay onboard, and $\mathrm{H}$. K. Olsen for assistance in the field.

\section{References}

Clarke, D. B. \& Pedersen, A. K. 1976: Tertiary volcanic province of West Greenland. In Escher, A. \& Watt, W. S. (edit.) Geology of Greenland, 365-385. Copenhagen: Geol. Surv. Greenland.

Du Toit, A. L. 1907: Pipe-amygdaloids. Geol. Mag. 44, 13-17.

Fuller, R. E. 1931: The aqueous chilling of basaltic lava on the Columbia River Plateau. Am. J. Sci. 21, 281-300.

Larsen, J. G. in press: Geological map of Greenland 1:100 000 Igdlorssuit, 71 V. 1 Syd. Copenhagen: Geol. Surv. Greenland.

Rosenkrantz, A. \& Pulvertaft, T. C. R. 1969: Cretaceous-Tertiary stratigraphy and tectonics in northern West Greenland. Mem. Am. Ass. Petrol. Geol. 12, 883-898.

Russel, I. C. 1902: Geology and water resources of the Snake River plains of Idaho. Bull. U.S. geol. Surv. 199, 192 pp.

Schmincke, H.-U. 1967: Flow directions in Columbia River basalt flows and paleocurrents of interbedded sedimentary rocks, south Central Washington. Geol. Rsch. 56, 992-1020.

Waters, A. C. 1960: Determination of flow in basalts. Am. J. Sci. $258 \mathrm{~A}, 350-366$. 